\title{
Karyotypic characterization of Hydromedusa tectifera (Testudines, Pleurodira) from the upper Iguaçu River in the Brazilian state of Paraná
}

\author{
Rafael Bueno Noleto ${ }^{1}$, Daniel Luis Zanella Kantek ${ }^{1}$, Ana Cláudia Swarça ${ }^{2}$, Ana Lúcia Dias ${ }^{2}$, \\ Alberto Sergio Fenocchio ${ }^{2,3}$ and Marta Margarete Cestari ${ }^{1}$ \\ ${ }^{1}$ Universidade Federal do Paraná, Departamento de Genética, Curitiba, PR, Brazil. \\ ${ }^{2}$ Universidade Estadual de Londrina, Departamento de Biologia Geral, Londrina, PR, Brazil. \\ ${ }^{3}$ Universidad Nacional de Misiones, Departamento de Genética, Posadas, Misiones, Argentina.
}

\begin{abstract}
We present the karyotypic characterization of 26 specimens of the side-necked turtle Hydromedusa tectifera collected in the upper Iguaçu River, Paraná state, Brazil. The turtles were cytogenetically analyzed using Giemsa staining and other banding techniques ( $, \mathrm{G}, \mathrm{Ag}-\mathrm{NOR}$ and $\mathrm{CMA}_{3}$ ) as well as fluorescence in situ hybridization $(\mathrm{FISH})$ with a rDNA $18 \mathrm{~S}$ probe. All the specimens showed a diploid number of 58 composed of 22 macro and 36 microchromosomes. The Ag-NOR, $\mathrm{CMA}_{3}$ and FISH techniques permitted the identification and characterization of the chromosome pairs bearing nucleolus organizer regions (NORs), while G-banding facilitated a better recognition and pairing of macrochromosomes. These data agree with some information available in the literature and should be very useful for further cytotaxonomic and cytosystematic studies.
\end{abstract}

Key words: chromosomes, FISH, G-banding, pleurodira, turtle.

Received: May 5, 2005; Accepted: Septemer 21, 2005.

\section{Introduction}

Turtles of the suborder Pleurodira are divided into two families, the Chelidae and the Pelomedusidae, which are clearly separated by both morphological (Gaffney, 1977) and molecular (Shaffer et al., 1997) features. The Chelidae consists of nine genera, five of which are found in Australia and New Guinea and four in South America (Ernst and Barbour, 1989). Conflicting phylogenies have been proposed for the Chelidae, but recent phylogenetic analysis based on molecular markers (Seddon et al., 1997; Fujita et al., 2004) support the monophyly of the Australian/New Guinea and South American chelid turtles. The chelid genus Hydromedusa (commonly known as snakenecked turtles) consists of two species of semi-aquatic turtles that have an extremely long throat: $H$. maximiliani, restricted to the southeast region of Brazil; and H. tectifera, distributed throughout southern and southeastern Brazil, northeastern Argentina, Uruguay and southeastern Paraguay.

Send correspondence to Rafael Bueno Noleto. Universidade Federal do Paraná, Centro Politécnico, Departamento de Genética, Caixa Postal 19071, 81531-990 Curitiba, PR, Brazil. E-mail: rafanoleto@yahoo.com.br.
The chromosomes of birds, fishes and some reptile groups are highly variable in terms of size and morphology, and are characterize by bimodal or asymmetric karyotypes composed of macro and microchromosomes. Turtle karyotypes show two general tendencies based on the presence or absence of microchromosomes but there is much variation between groups. For example, the chromosome number in the order Chelonia ranges from $2 \mathrm{n}=26$ in Podocnemis dumeriliana (Ayres et al., 1969) to $2 \mathrm{n}=96$ in Platemys platycephala (Bull and Legler, 1980; Bickham et al., 1985). Also, while karyotypic studies have frequently been published for turtles from the suborder Cryptodira, information about Pleurodires is scarce and fragmented and mainly based on conventional staining techniques.

In this paper describe the almost complete karyotypic characterization of Hydromedusa tectifera using several staining techniques and in situ Fluorescence Hybridization (FISH).

\section{Material and Methods}

We studied 26 Hydromedusa tectifera specimens (11 male, 11 female and four unsexed), originally from the first plateau of the Iguaçu River, near the city of Araucária in the 
Brazilian state of Paraná. The chromosomes were obtained either from peripheral blood samples which had been directly treated with colchicine for six hours or from lymphocyte culture (Fenocchio and Bertollo, 1988). The chromosomal preparations were air-dried and conventionally stained with Giemsa, besides the C-, G- bandings and silver-staining according to Sumner (1972), Seabright (1971) and Howell and Black (1980) respectively. The GC-specific fluorochrome chromomycin A3 $\left(\mathrm{CMA}_{3}\right)$ was used according to Verma and Babu (1995). The rDNA $18 \mathrm{~S}$ probe (about $1800 \mathrm{bp}$ ), obtained from the nuclear DNA of the fish Oreochromis niloticus, was used for in situ hybridization according to Heslop-Harrison et al. (1991), with alterations. Chromosomes were measured and arranged in decreasing order of size according to Levan et al. (1964).

\section{Results and Discussion}

The chromosome complement of all our Hydromedusa tectifera specimens was $2 \mathrm{n}=58$, of which 22 were macrochromosomes and 36 microchromosomes (Figure 1a). It was possible to precisely determine the position of the centromere in the macrochromosomes, and we observed one submetacentric chromosome pair, one metacentric pair and nine pairs of acrocentric chromosomes, giving a total of 62 chromosome arms. No sex chromosome heteromorphism was observed. This diploid number agrees with the study of Bull and Legler (1980), which investigated H. tectifera from an undefined area of South America. The fact that the third pair of the $H$. tectifera complement is acrocentric is a special and differential feature of $H$. tectifera, in contrast to other Chelids that have the first three pairs biarmed (Bull and Legler, 1980).
The G-banding permitted the visualization, especially in the macrochromosomes, of a pattern of bands that enabled better identification and pairing of the chromosomes as well as the construction of an ideogram (Figure 1b). Such a pattern is similar, but not identical, to that observed in other Pleurodiran turtles, due to the presence and absence of some bands when compared to the patterns found by Bull and Legler (1980) in Pelomedusoid turtles (a group related to the Chelidae). This variation in the Gbanding pattern in Pleurodiran turtles establishes a different karyotypic evolution from that identified for the suborder Cryptodira. Previous reports have suggested genomic stability in Cryptodiran turtles, in which both the banded chromosome morphology (Bickham, 1981) and the DNA sequences inside the chromosomes (Muhlmann-Díaz et al., 2001) remain unchanged for millions of years.

Only one NOR site was detected in the silver-stained cells analyzed, this site being only on the telomere of the long arm of the acrocentric microchromosome (Figures 2a and $2 \mathrm{~b}$ ) and this region presented positive signals after Chromomycin A3 staining, therefore being rich in GC base pairs (Figure 2c). Silver-staining did not show the inactive site on the homologue chromosome but FISH using the rDNA $18 \mathrm{~S}$ probe revealed it and confirmed the number and location of the ribosomal genes (Figure 2d).

We observed positive C-bands in the centromeric region of most chromosomes, even the microchromosomes, which were mainly euchromatic (Figure 2e). The amount of $\mathrm{C}$-band heterochromatin in Chelids is variable, varying from scarce in H. tectifera and in the genus Chelus, to moderate in the genus Chelodina where it occupies a complete chromosomal arm (Bull and Legler, 1980).

Therefore, this study provides a relevant specific characterization of Hydromedusa tectifera from the Iguaçu
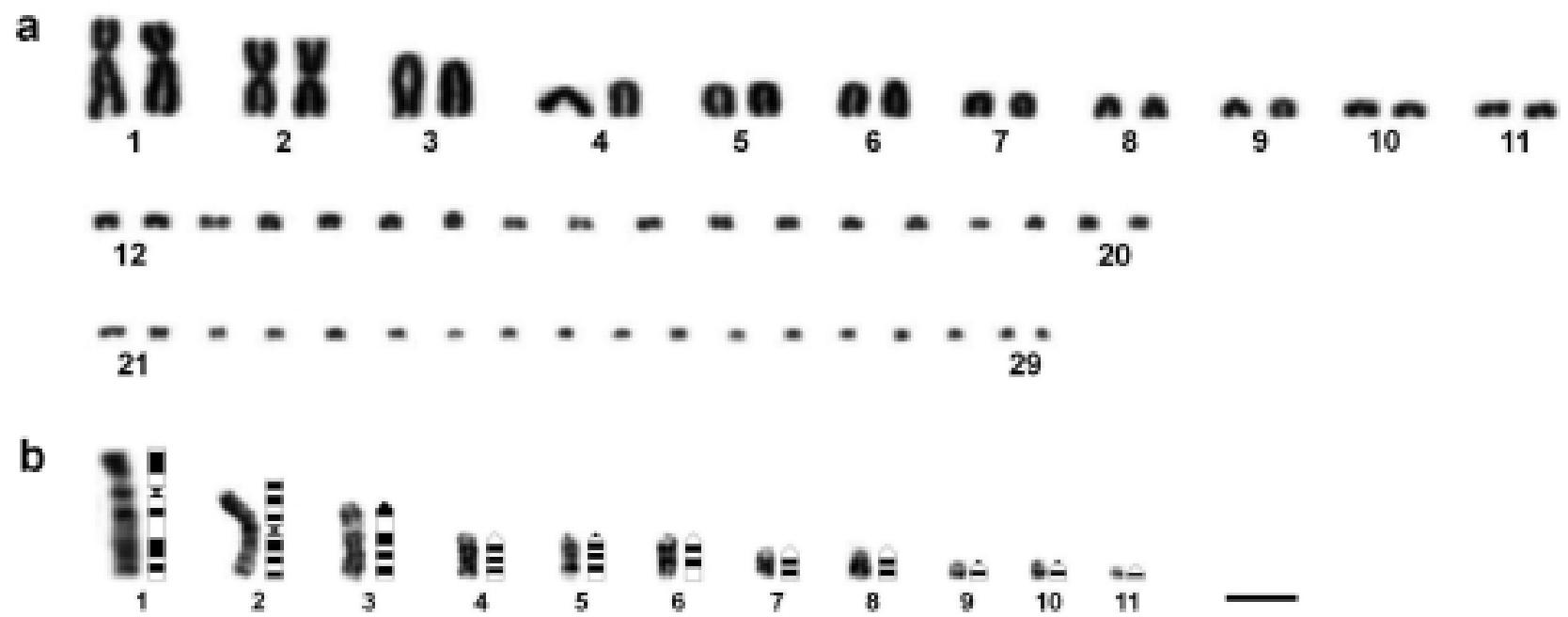

Figure 1 - Karyotype of Hydromedusa tectifera with $2 \mathrm{n}=58$ chromosomes (a). G-banded karyotype showing the 11 pairs of macrochromosomes with the respective ideogram (b). Bar $=5 \mu \mathrm{m}$. 


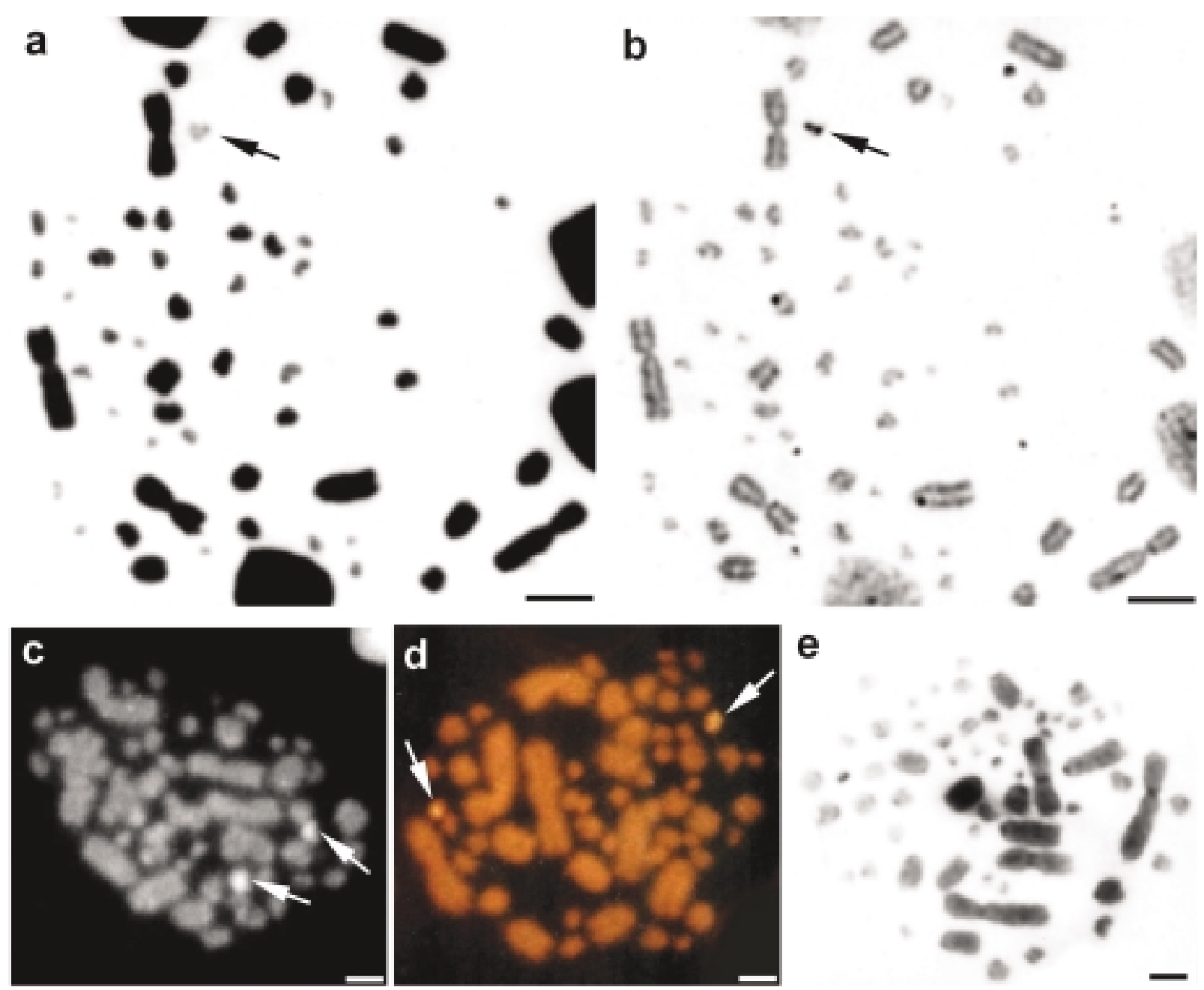

Figure 2 - Different stained metaphases of Hydromedusa tectifera: sequential staining of a metaphase plate with Giemsa (a) and $\mathrm{AgNO}_{3}(\mathrm{~b})$. The arrow indicates only one Ag-NOR site. (c) $\mathrm{CMA}_{3}$ staining, (d) FISH with the $18 \mathrm{~S}$ rDNA probe showing the rDNA sites. The arrows show the nucleolar chromosomic pair. (e) C-banding pattern. Bars $=5 \mu \mathrm{m}$.

River (PR). The findings may be useful for more accurate comparative cytogenetic studies regarding its karyotypic evolution between turtle groups.

\section{Acknowledgments}

We thank Professor Rogério R. Lange (Universidade Federal do Paraná) for assistance in collecting the turtle blood and the Brazilian company PETROBRÁS for financial support of this study.

\section{References}

Ayres M, Sampaio MM, Barros RMS, Dias LB and Cunha OR (1969) A karyological study of turtles from the Brazilian Amazon region. Cytogenetics 8:401-409.

Bickham JW (1981) Two-hundred-million-year-old chromosomes: Deceleration of the rate of karyotypic evolution in turtles. Science 212:1291-1293.
Bickham JW, Tucker PK and Legler JM (1985) Diploid-triploid mosaicism: An unusual phenomenon in side-necked turtles (Platemys platycephala). Science 227:1591-1593.

Bull JJ and Legler JM (1980) Karyotypes of side-necked turtles (Testudines, Pleurodira). Canadian J Zool 58:828-841.

Ernst CH and Barbour RW (1989) Turtles of the World. Smithsonian Institution Press, Washington DC, 313 pp.

Fenocchio AS and Bertollo LAC (1988) A simple method for fresh-water lymphocyte culture. Rev Bras Genet 11:847852.

Fujita MK, Engstrom TN, Starkey DE and Shaffer HB (2004) Turtle phylogeny: Insights from a novel nuclear intron. Mol Phylogenet Evol 31:1031-1040.

Gaffney ES (1977) The side-necked turtle family Chelidae: A theory of relationships using shared derived characters. Am Mus Novitates 2620:1-28.

Heslop-Harrison JS, Schwarzacher T, Anamthawat-Jónsson K, Leitch AR, Shi M and Leitch IJ (1991) In situ hybridization with automated chromosome denaturation. Technique 3:109-115. 
Howell WM and Black DA (1980) Controlled silver staining of nucleolus organizer regions with a protective colloidal developer: A 1-step method. Experientia 36:1014-1015.

Levan A, Fredga K and Sandberg A (1964) A Nomenclature for centromeric position on chromosomes. Hereditas 52:201220.

Muhlmann-Díaz MC, Ulsh BA, Whicker FW, Hinton TG, Congdon JD, Robinson JF and Bedford JS (2001) Conservation of chromosome 1 in turtles over 66 million years. Cytogenet Cell Genet 92:139-143.

Seabright M (1971) A rapid banding technique for human chromosome. Lancet 2:71-972.
Seddon JM, Georges A, Braverstock PR and McCord W (1997) Phylogenetic relationships of chelid turtles (Pleurodira, Chelidae) based on mitochondrial 12S rRNA gene sequence variation. Mol Phylogenet Evol 7:55-61.

Shaffer HB, Meylan P and McKnight ML (1997) Tests of turtle phylogeny: Molecular, morphological and paleontological approaches. Syst Biol 46:235-268.

Sumner AT (1972) A simple technique for demonstrating centromeric heterochromatin. Exp Cell Res 75:304-306.

Verma RS and Babu A (1995) Human Chromosomes: Principles and Techniques. 2nd edition. McGraw-Hill, New York, $419 \mathrm{pp}$.

Associate Editor: Yatiyo Yonenaga-Yassuda 